\title{
BENCHMARK ANALYSIS FOR PLASTIC RECYCLATES IN AUSTRIAN WASTE MANAGEMENT
}

\author{
Karl Friedrich *, Selina Möllnitz, Stephan Holzschuster, Roland Pomberger, Daniel Vollprecht \\ and Renato Sarc
}

Montanuniversitaet Leoben, Department of Environmental and Energy Process Engineering, Chair of Waste Processing Technology and Waste Management, Franz-Josef-Straße 18, A-8700, Leoben, Austria

Article Info:
Received:
8 July 2019
Revised:
27 September 2019
Accepted:
25 October 2019
Available online:
20 November 2019
Keywords:
Polymers
Recyclates
Quality
Price
Correlation
Circular economy

\section{INTRODUCTION}

The European plastic strategy presented by the European Commission, to be implemented in the Recycling Sector Package, poses an enormous challenge for the European waste management and the plastics processing industry. The circular economy package sets a recycling rate of 55 wt.\% by 2030 for plastic packaging waste (European Union, 2018). The European Commission has not stipulated a compulsory percentage of recycled plastics in the manufacturing process of new consuming products, i.e. substitution rate on a primary raw material level. Moreover, the Commission appeals to the responsibility of manufacturers to achieve its objectives regarding circular economy.

Currently, recyclates are applied with a content lower than $10 \%$ in new plastic packaging products (Reitz, 2019). This suggests that recyclates are either too expensive or of too low quality. Although scientific studies (Klumpp \& Su, 2018; Martel, 2018; Pauwels \& D’Aveni, 2014; Voros, 2019; Zhe Gin \& Kato, 2010) have already focused on the correla- tion of quality and price for other goods, this paper does not only examine such correlations but also includes quality parameters for the sorted plastic waste and recyclates to provide a practical guideline for quality assurance. In the course of the applied survey for this paper, experts gave a comprehensive overview of how quality is assessed in the field and which parameters are significant for high quality material. Furthermore, this data will support assessing the economic feasibility of certain stages of plastic packaging waste treatment (European Committee, 2019).

Wide range of composited materials and problematic additives can lead to sales difficulties for recyclates too, since recycled materials from "older" waste plastics may still contain substances that are no longer permitted in new plastics due to their negative effects on the environment and health (Wilts et. al., 2014). Plastic recycling is also limited by a lack of quality and constant supply of raw materials required by the industry (Vilaplana \& Karlsson, 2008). Quality criteria for recyclates for the final plastic processing companies are not standardised but defined individu- 
ally by the recycling and processing companies. Criteria include exceptionally pure colour and low content of contaminations (Vilaplana \& Karlsson, 2008). Besides the lack of quality, the poor image of recycled plastics in the public also impairs plastic recycling (Moser et. al., 2016). As a result, recyclates are not used in new plastic products to the desired extent or not at all.

Despite the number of obstacles, however, recyclates are increasingly applied by the industry to pursue a sustainable strategy (Polymer Comply Europe, 2017). The market for primary raw plastics is characterized by:

- A close correlation with the price of crude oil, resulting in comparatively high volatility of prices. As a result, when the price of primary raw plastic significantly decreases, recyclates will be increasingly substituted by primary raw material granulate, as well as

- Easy substitutability of products of different suppliers and also by oligopolistic market structures, inspiring strategic behaviour of suppliers (Rothgang et. al., 2017).

The main question raised by this paper is based on these two findings and seeks to establish a correlation between the price and the quality of plastic recyclates. In addition, the quality requirements for sorted plastic waste and produced recyclates are examined. The importance of quality assurance and its practical implementation are treated in a separate section. Furthermore, the market for primary raw plastics and recyclates is examined in detail and pricing developments are analyzed.

\section{MATERIALS AND METHODS}

\subsection{Materials}

The following plastic types are being investigated in the study as they represent $57 \%$ of the demand for the plastic packaging waste processing industry in Austria (Stoifl et. al., 2017):

- High-density polyethylene (HDPE) foils and hollow bodies (emptied);
Low-density polyethylene (LDPE) foils and hollow bodies (emptied);

- Polypropylene (PP) foils and dimensionally stable PP (bucket, canister, emptied);

- Polyethylene terephthalate (PET) bottles (emptied);

- Polystyrene (PS) foils (thermoforming film).

This paper mainly discusses recyclates since regrind materials do not undergo extensive quality assurance and, frequently, only the impurity content is of importance.

\subsection{Methods}

All relevant stakeholders along the value chain from plastic wastes to the finished products are shown in Figure 1. This figure also shows all the terms used in this paper along the presented value chain.

A market analysis of secondary plastic granulates was conducted to identify the quality benchmark in plastic recyclates, performed by observing the development of pricing, identifying drivers to the increase or decrease of value and verifying whether the value depends on recyclate quality or on other economic features.

To analyse the correlation between price and quality, several packaging plastic waste processing companies and plastic waste recycling companies were provided with a specially designed assessment guide. In addition to personal discussion with plastic waste recyclers and the plastic waste processing industry in Austria, the plastics recyclers and the plastics processing industry in Germany was approached with short and targeted e-mail questions. Altogether, 19 different stakeholders responded. Six phone calls were made, reaching two plastic recyclers, three plastics processing companies and one association. In addition, about 80 e-mails were sent to plastic waste collectors, plastics recyclers and plastics processing companies, resulting in a return rate of approximately $20 \%$. Four plastics recyclers, five plastic processing companies and four other stakeholders responded. Figure 2 shows the distribution of the consulted companies by industry. $32 \%$ of plastic re-

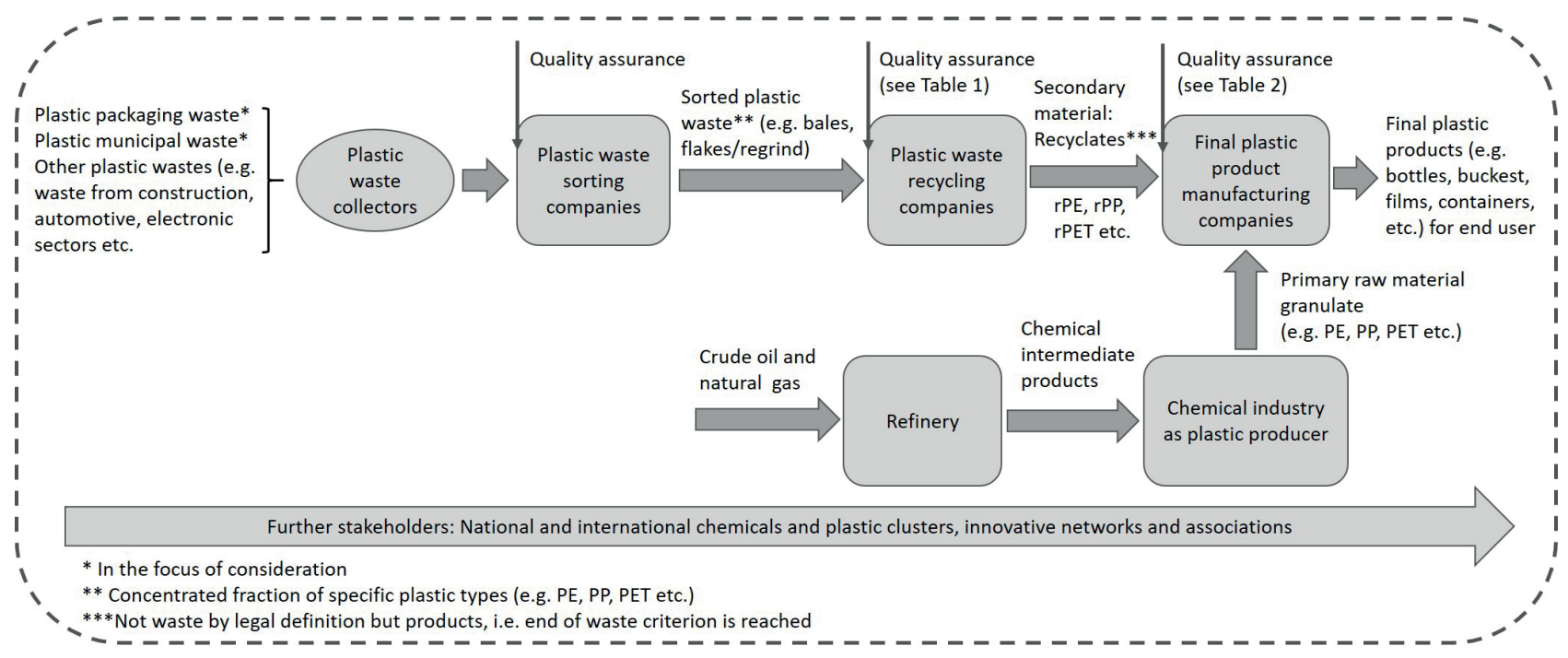

FIGURE 1: Stakeholders along the value chain from plastic waste to final plastic products. 


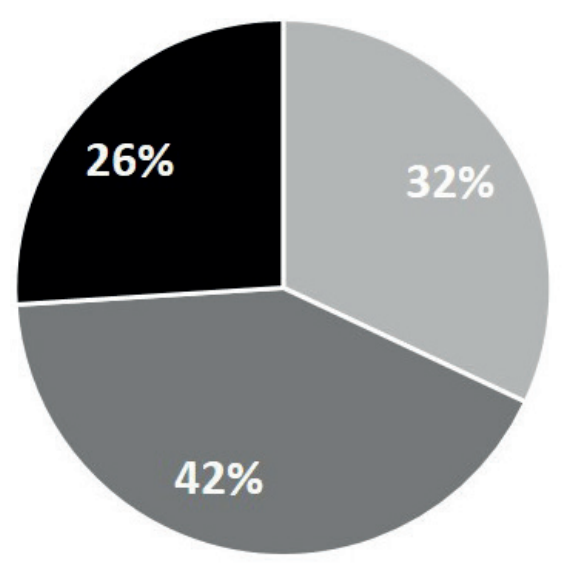

- Plastics waste recycling companies

- Final plastic product manufactoring companies

- Others (cluster, associations, societies or research institutes)

FIGURE 2: Distribution of the consulted companies by industry.

cyclers, $42 \%$ of plastic processing companies and $26 \%$ of other stakeholders along the plastic value chain participated the survey. The other stakeholders are cluster, associations, societies or research institutions operating in the field of plastics processing.

\section{RESULTS AND DISCUSSION}

The following section is divided into five subsections. First, the quality requirements for the sorted plastic waste and the plastic recyclates are shown. Second, the section "Quality Control" is describing, which parameters are significant for reliable quality control for the sorted plastic waste and manufactured recyclates. Additionally, price development for the polymer types mentioned above has been done. Furthermore, the most relevant questions of this study are answered in a separate section. Finally, to fulfil the titles of this paper, the quality benchmark in plastics recyclates are described.

\subsection{Quality Requirements}

Requirements for sorted plastic waste qualities:

In Germany, quality standards for sorted plastic waste applied in the plastic waste recycling companies have evolved within the plastic industry (Grüner Punkt, 2019), summarized in Table 1.
Quality requirements for produced recyclates:

Provided specification sheets or datasheets of produced recyclates include limit ranges (see Table 2) for the following properties:

- The density of non-cellular plastics (DIN EN ISO 1183-1)

- Melt volume-flow rate (MVR), melt-mass flow rate (MFR) and flow rate ratio (DIN EN ISO 1133-1)

- Tensile properties, in particular, modulus of elasticity (E-Modul) (DIN EN ISO 527-1)

- Notch impact strength (DIN EN ISO 179/1eA)

\subsection{Quality assurance}

\subsubsection{Quality assurance of plastic waste}

The key competence in the quality assurance process of the delivered mixed plastic waste material to the plastic waste sorting plant is found with the material acceptance staff. Based on their experience, the quality of supplied plastic waste bales can be assessed by visual inspection. Attention is paid to coarse impurities. The collective experience of the stuff is decisive. An essential part of the input control is the colour distribution of the bale because a majority of pure plastics is a requirement for the production of high-quality recyclates and their use in new products.

Furthermore, the origin of waste affects the assessment of the sorted plastic waste quality. Hence, the materi-

TABLE 1: Quality standards for sorted plastic wastes for recycling (Grüner Punkt, 2019).

\begin{tabular}{|c|c|c|c|c|c|c|c|c|}
\hline $\begin{array}{l}\text { Sorted plastic } \\
\text { wastes }\end{array}$ & $\begin{array}{l}\text { Metal items } \\
\text { [wt.\%] }\end{array}$ & $\begin{array}{l}\text { Other plastic } \\
\text { particles } \\
\text { [wt.\%] }\end{array}$ & $\begin{array}{l}\text { Other } \\
\text { residues }{ }^{1)} \\
\text { [wt.\%] }\end{array}$ & $\begin{array}{l}\text { Dimensional- } \\
\text { ly stable PE } \\
\text { articles } \\
\text { [wt. \%] }\end{array}$ & $\begin{array}{c}\text { Foamed } \\
\text { plastics incl. } \\
\text { EPS* } \\
\text { [wt. } \% \text { ] }\end{array}$ & $\begin{array}{l}\text { Plastic Foils } \\
\text { [wt.\%] }\end{array}$ & $\begin{array}{l}\text { PVC } \\
\text { [wt.\%] }\end{array}$ & $\begin{array}{c}\text { Dimensional- } \\
\text { ly stable PP } \\
\text { [wt.\%] }\end{array}$ \\
\hline $\begin{array}{l}\text { Plastic Foils } \\
\text { (mostly LDPE) }\end{array}$ & $<0.5$ & $<4.0$ & $<4.0$ & - & - & - & - & - \\
\hline $\begin{array}{l}\text { Plastic hollow body } \\
\text { (mostly HDPE) }\end{array}$ & $<0.5$ & $<3.0$ & $<3.0$ & - & - & - & - & - \\
\hline PP & $<0.5$ & - & $<3.0$ & $<1.0$ & $<0.5$ & $<2$ & - & - \\
\hline PET bottles & $<0.5$ & $<2.0$ & $<2.0$ & - & - & - & $<0.1$ & - \\
\hline PE & $<0.5$ & - & $<3.0$ & - & $<0.5$ & $<5.0$ & - & $<3.0$ \\
\hline PS & $<0.5$ & $<4.0$ & $<2.0$ & - & $<1.0$ & - & - & - \\
\hline
\end{tabular}

Compostable waste (foods, garden rubbish). * EPS: expanded polystyrene 
TABLE 2: Physical, chemical and rheological properties of the investigated recyclates (Grüner Punkt, 2019)

\begin{tabular}{|c|c|c|c|c|c|}
\hline Properties & LDPE & HDPE & PP & PET & PS \\
\hline Density $\left[\mathrm{g} / \mathrm{cm}^{3}\right]$ & $0.920-0.945$ & $0.940-0.970$ & $0.895-0.920$ & $1.360-1.390$ & $1.050-1.290$ \\
\hline $\begin{array}{l}\text { Melt-mass flow rate (MFR) } \\
\text { [g/10 min] }\end{array}$ & $0.5-0.9^{(1)}$ & $0.1-30.0^{(1)}$ & $0.1-30.0^{(2)}$ & $20.0-30.0^{(3)}$ & $2.3-8.2^{(4)}$ \\
\hline $\begin{array}{l}\text { Tensile properties (modulus of elasticity) } \\
\text { [MPa] }\end{array}$ & $220-380$ & $1170-1350$ & $850-1450$ & $3400-3700$ & $3000-3400$ \\
\hline Notch impact strength [kJ/m²] & $8.00-15.00$ & $4.85-5.15$ & $3.00-5.50$ & $2.00-4.00$ & $8.0-12.0$ \\
\hline
\end{tabular}

al flow can be assessed using empirical values depending on the origin.

There are interesting arguments why deliveries of sorted plastic waste bales are rejected. Cartridges for sealing compounds repeatedly lead to rejection. The moisture of bales is another argument. Increased moisture can affect the surface of the particles and foaming processes during injection moulding may occur. Basically, however, non-conformity with quality requirements usually leads to a price reduction. If the content of contaminants is too high, the processing is impaired (material variations).

\subsubsection{Quality control of recyclates}

The quality of random samples of recyclates is controlled in a laboratory. The physical, rheological and mechanical properties of the recyclates are of great interest. The following characteristics are analysed in the course of a random sample inspection:

1. Physical properties

a. density determination (DIN EN ISO 1183-1)

2. Rheological properties

a. melt-mass flow rate (MFR) (DIN EN ISO 1133-1)

3. Mechanical properties

a. tensile properties, especially modulus of elasticity

(DIN EN ISO 527-1)

b. notch impact strength DIN EN ISO 179/1eA

Frequently, further parameters of the recyclates are determined. These include:

- Melting temperature

- Colour distribution and colour composition

- Size and form of the granulated material (e.g. lenses, cylinder)

- Moisture content

- Filtration fineness

- Ash content

- Heavy metal content

In addition, there is often a continuous control of recyclates and an inspection for any specks, gas emissions, mechanical values and the colour of the recyclates.

The hardness of recyclates allows initial prediction of the foreign plastic content, the shape of the granulates and the bulk density indicating potential gas inclusions or vacuoles. The colour and odour of granulates may indicate previous thermal degradation of the material. The following devices or test methods are frequently used in quality assurance refers to the previously mentioned standard specifications: Melt index testers, differential scanning calorimetry (DSC), ash furnaces, residual moisture scales, density analysers, capillary rheometers, tensile testing and notched-bar impact test machine.

\subsection{Price Development}

The plastic trading market is currently shifting and, as mentioned before, increasingly developing into a buyer's market. A high dollar exchange rate $(1,1008$ \$/€ on 24Sept-2019) (Wallstreet-online, 2019) and weak crude oil prices (62.90 \$/barrel on 24-Sept-2019) (Tecson, 2019) result in a preference for primary raw material over recyclates. Moreover, the European plastic market has changed due to the ban of exports to China that has previously been one of the largest importers of European plastic waste.56\% of all plastic waste worldwide and $87 \%$ of all European plastic waste has been sent to China in recent years (Uken, 2018). The plastic waste streams, which are heavily contaminated and poorly sorted are most seriously affected. As a result, there is an oversupply of this plastic wastes in the European plastic recycling market. It follows that the plastics processing industry will favour high quality of plastics available.

Plastic wastes with low extraneous and pollutant contents and lower humidity are demanded. This oversupply of polluted plastic waste enables customers to select highest-quality plastic waste, ultimately affecting the pricing. Low-quality plastic waste losing market shares used to a great extent for thermal treatment or recovery (Sarc et. al., 2019).

\subsubsection{Price development for sorted plastic waste}

The price developments for HDPE and LDPE (A), PP (B), PET (C) and PS (D) regrinds and bales over the last years are shown in Figure 3. The average selling price for regrinds of commodity plastics (e.g. PE, PP, PET, PS) is about $538 € / t$, varying by $92 € / t$ (Plasticker, 2019).

For the PE types, it is stated that the average regrind price is very similar for HDPE and LDPE with approximately $0.6 € / \mathrm{kg}$ (Plasticker, 2019). The HDPE regrind price fluctuated significantly more than LDPE in the years 2014 to 2017. The LDPE regrind price is on average three times higher than the prices for the LDPE bales. This can also be observed for PP and PET. At $0.56 € / \mathrm{kg}$, the average regrind price for PP is 2.5 times higher than for PP bales, and at $0.37 € / \mathrm{kg}$, the average regrind price for PET is 1.9 times higher (Plasticker, 2019). The reason for this is the higher processing depth and the associated higher costs for the production of regrinds compared to bales. The different 

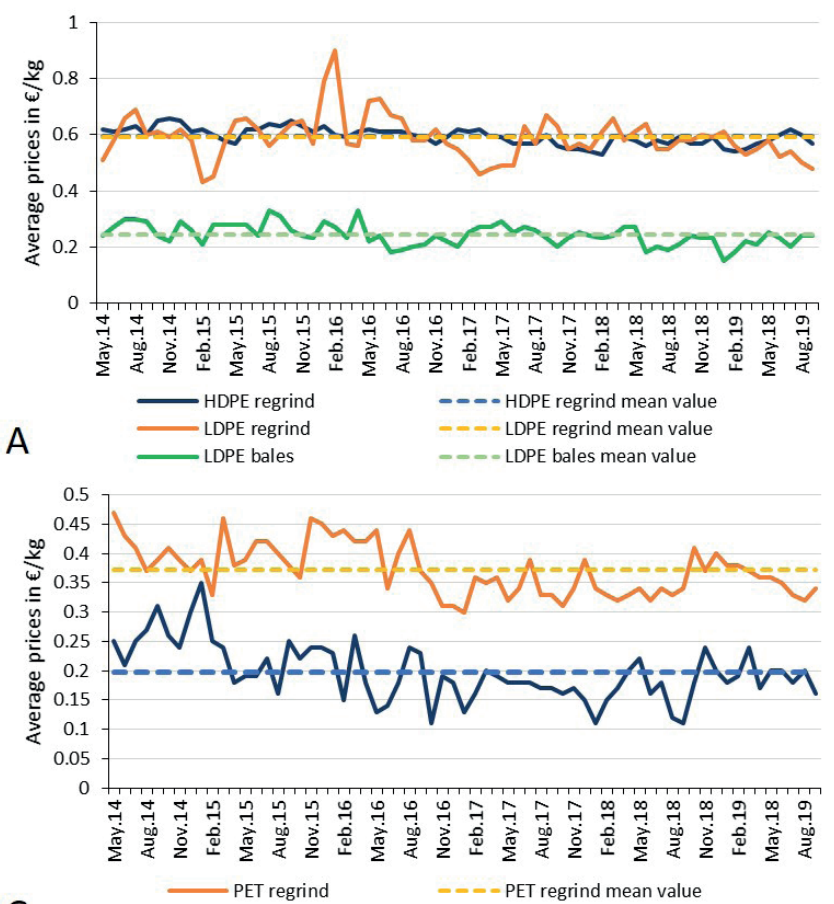

C

- PET bales

- - PET bales mean value
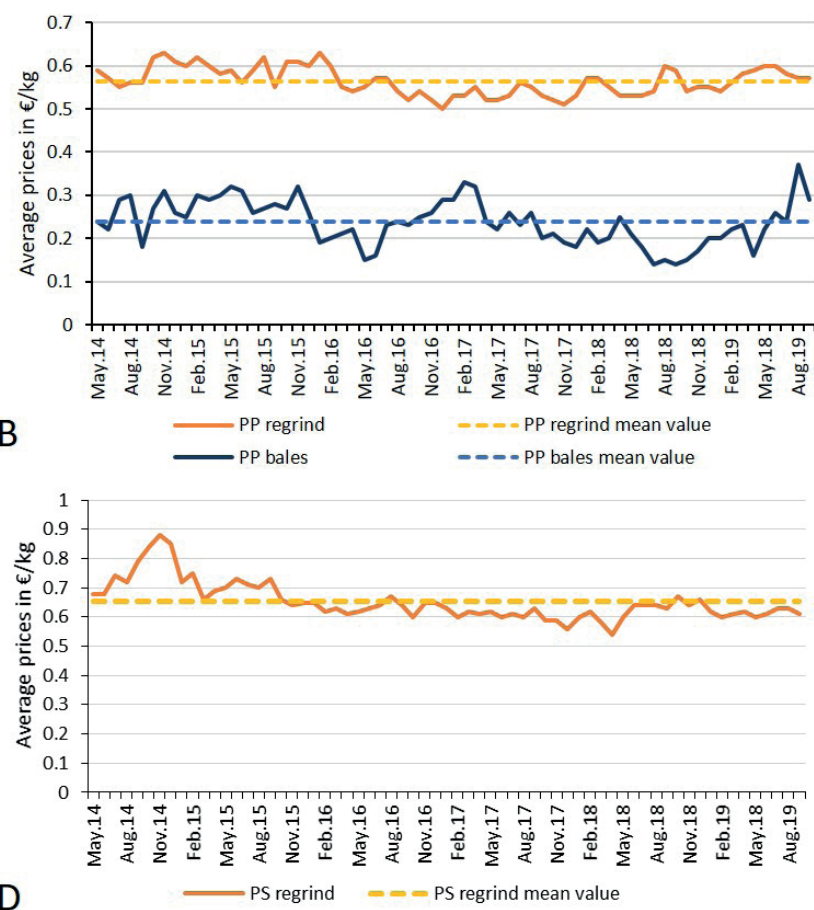

FIGURE 3: Price development for regrinds and bales of PE types (A), PP (B), PET (C) and PS (D) (Plasticker, 2019).

price differences between regrinds and bales of the plastic types can be explained by the different processing costs.

\subsubsection{Price development for recyclates}

The price developments for LDPE (A), HDPE (B), PP (C) and PS (D) granulates of primary raw materials and recyclates are shown in figure 4 . No reliable price development could be collected for PET. The average selling price in July 2019 of primary raw material granulates of standard plastics (e.g. PE, PP, PS, PET) was around $1.17 € / t$ and 0.537 $€ / t$ (Plasticker, 2019) was the average selling price of recyclates of standard plastics. This means that granulates produced of primary raw material are on average twice as expensive as recyclates.

A comparison of the price developments of the primary raw materials with those of recyclates shows that there is a certain dependency between both price developments. If the price of a primary raw material rises or falls, the recyclate price of this plastic type also reacts with a price rise or fall. This fact can be seen for example well for LDPE in Figure $4(\mathrm{~A})$.

\subsection{Market Study}

The following section provides a summary of the most important statements:

\section{Is there a correlation between price and quality of the sorted plastic waste?}

First, the general market balance of supply and demand is pointed out. This provides the basis for any pricing. Where supply and demand meet, a corresponding market for goods develops.

The respondents 'affirm' the question, though. There is indeed a strong correlation between the quality and price of the sorted plastic waste. In addition, better application options are made accessible by purer sorted plastic waste, higher-priced. Surveyed plastic processing companies also reported the dependence of co-payments, i.e. a negative price for recyclates. If the sorted plastic waste can be purchased for a higher additional price, then the recyclates may be offered for less. When co-payments decline, however, the prices in sales have to rise. Additional payments depend primarily on the quality of the sorted plastic waste. If the material is dirty and includes high amounts of extraneous plastic, additional payments are higher. It the material is clean, on the other hand, and has a low level of extraneous plastics, additional payments will be lower.

It was also mentioned that the quality of the sorted plastic waste is primarily defined by its colour. The higher its purity, the higher the price that can be achieved on the plastic trade market. This is mainly due to its broader application range, say, in subsequent colouring, foil thickness and mechanical properties.

As mentioned above, the staff is crucial for sorted plastic waste price. They ultimately control the quality and their wealth of experience facilitates a reliable quality level and, accordingly, adequate pricing.

\section{Is there a correlation between price and quality of the re- cyclates?}

Regarding this question, there is again a general agreement on a higher quality of recyclates leading to higher prices. It is backed by the argument that higher quality of the recyclate reduces the risk of failures or bad batches from contamination for final plastic processing companies. Furthermore, it was mentioned that the quality of the 

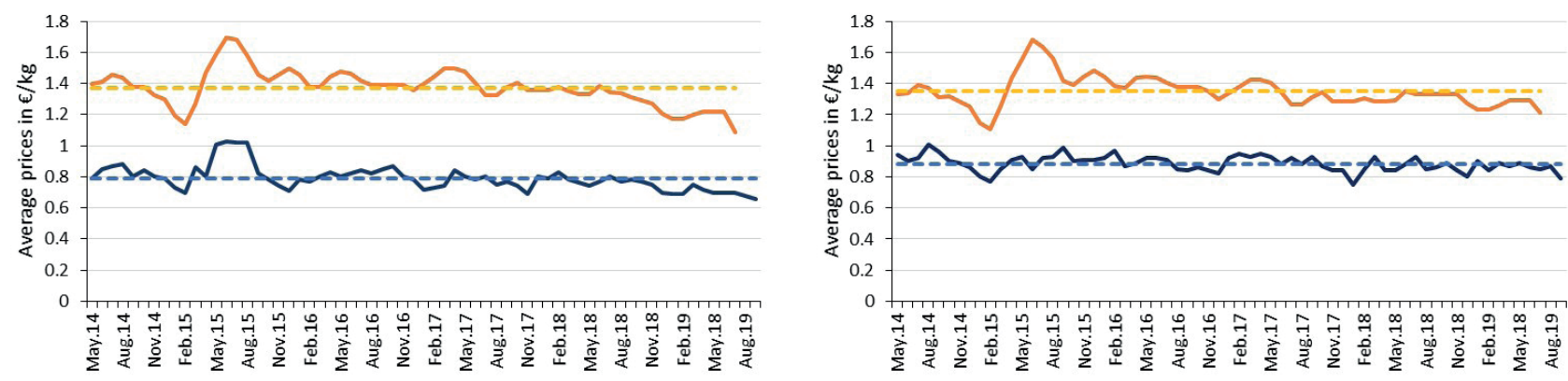

A
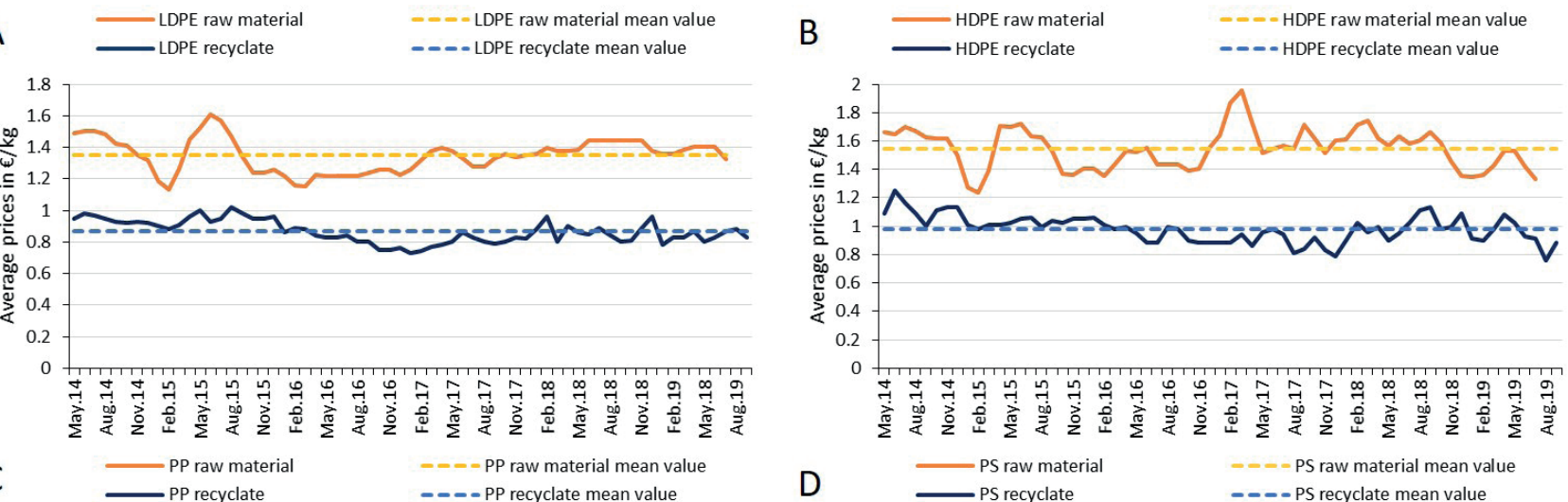

FIGURE 4: Price development for primary raw material and recyclates of LDPE (A), HDPE (B), PP (C) and PS (C) (Plasticker, 2019).

sorted plastic waste strangely affects the quality of the produced recyclates.

\section{Pricing of recyclates}

Basically, the market mechanisms of supply and demand apply. In addition, the following criteria were identified for pricing recyclates:

- Purity: the purer a material, the broader its range of application and the higher the price potentially achieved;

- Colour purity: the purer the colour of recycled material, the broader its range of application and the higher the price potentially achieved;

- A function of the primary raw material prices: Pricing polymer types is a function of the respective commodity price. If the price of primary raw material decreases, the price of polymers will drop as well. Recyclate prices are usually following the trend.

Other pricing contributors are melt filtration in the context the lower the melt filtration (measured in $\mu \mathrm{m}$ ), the higher the quality and cost supplement for masterbatches. When plastic is dyed, a certain amount will be charged for this procedure, raising the price.

\subsection{Quality benchmark in plastics recyclates}

Market analysis has not produced any evidence for plastics recyclate benchmark. Therefore, producers of recyclates were asked to give one.

The surveys indicated that the quality standards for recyclates from Grüner Punkt (2019) are considered as a benchmark in the industry. For the recyclate quality, two levels are distinguished: mean quality for standard products like flower pots or buckets in 'standard plants' and high quality surpassing defined threshold values from Grüner Punkt (2019).

The demand for plastic recyclates is higher now than the recycling market is able to provide. For this reason, primary raw plastic granulates are mostly about 40 to $60 \%$ (see Figure 4) more expensive than plastic recyclates compared by the market data. The quality of recyclates is below that of primary raw plastic granulates regarding material properties but the consumers would tolerate it for the sake of sustainability. Better recyclability of plastics might reduce the market value of plastic recyclates. As best plastic recyclate quality, i.e. the benchmark, is met by plastic recyclates applied to food packaging like 'cap-to-cap' or 'bottle-to-bottle' production referring to the surveyed plastic processing companies.

\section{CONCLUSIONS}

The essential question was whether a correlation between price and quality of plastics recyclates is perceived. Experts from the plastics product manufacturing companies and plastics recyclers confirmed it unequivocally: The higher the quality of the material, the lower the impurities and the purer the material, the more applications for the material exist.

For sorted plastic waste, the plastic waste recycling companies quality standards defined by Grüner Punkt (2019) are considered a benchmark while recyclates applicable as food packaging (like cap-to-cap or bottle-to-bottle) constitute a benchmark for plastic recyclates.

In addition to the general market mechanisms of supply and demand, the pricing of secondary plastics is mainly a function of the purity of the recyclate, the purity of the co- 
lour and the respective price of raw materials. The purer and the cleaner the material, the higher the price that can be achieved on the market. The impact of respective commodity prices is also linked to the crude oil price and the dollar exchange rate.

Furthermore, the key competence of the staff in terms of quality control must be underlined. Their experience allows fast and reliable control, essential for successful further processing. For the quality control of recycled material, physical, rheological and mechanical properties are identified. In addition to density and melt flow rate, tensile properties and impact strength are identified to assure the required quality.

Plastic waste recycling companies would very much welcome a stipulation of minimum requirements for sorted plastic waste and recyclates by legislation.

Finally, it can be stated that, although the use of recyclates is facing some obstacles, many plastic product manufacturing companies are using plastic recyclates in their spite. There is a need for further changes at the political level (note: very positive example is "plastic strategy" of the EU) to help achieve a breakthrough. Many stakeholders along the plastic value chain would favour the further international introduction of quality standards. In addition, raising public awareness of the value of plastic waste is of key importance for further developments in the use of recycled plastic. Therefore, a package of measures and tools is needed to reduce obstacles and to promote high-quality plastics recycling as well as the use of recyclates.

\section{FUNDING}

Partial funding of this work was provided by:

The Competence Center for Recycling and Recovery of Waste 4.0 (acronym ReWaste4.0) (contract number 860 884) under the scope of the COMET - Competence Centers for Excellent Technologies - financially supported by BMVIT, BMWFW and the federal state of Styria, managed by the FFG.

\section{ACKNOWLEDGEMENTS}

The authors are very grateful to their students Stephan Holzschuster and Lisa-Maria Krois, who were actively supporting the authors during the data collection and evaluation.

\section{REFERENCES}

DIN EN ISO 179-1 (2010). "Plastics - Determination of Charpy impact properties - Part 1: Non-instrumented impact test". Published in November 2010. DOI: 10.31030/1625765.

DIN EN ISO 527-1 (2018). "Plastics - Determination of tensile properties - Part 1: General principles". Published in August 2018. DOI: $10.31030 / 2861408$.

DIN EN ISO 1133-1 (2012). "Plastics - Determination of the melt massflow rate (MFR) and melt volume flow rate (MVR) of thermoplastics - Part 1: Standard method". Published in March 2012. DOI: $10.31030 / 1818790$.

DIN EN ISO 1183-1 (2018). "Plastics - Methods for determining the density of non-cellular plastics - Part 1: Immersion method, liquid pyknometer method and titration method (ISO/DIS 1183- 1:2018)". Published in March-2018. DOI: 10.31030/1887611.
European Union (2018). “Directive (EU) 2018/852 of the European Parliament and the Council of 30 May 2018 amending Directive $94 / 62 / E C$ on packaging and packaging waste". Official Journal of the European Union. L 150/141.

Grüner Punkt (2019). Infos für Lieferanten. Spezifikationen für Wertstoff-Fraktionen (Information for suppliers. Specifications for recyclable fractions.). Accessed on 23-Sept-2019 at 11:55 a.m.: https://www.gruener-punkt.de/de/downloads.html.

Klumpp T., Su X. (2018). "Price-quality competition in a mixed duopoly". Wiley Journal of Public Economic Theory. Vol. 21. pp. 400-432. DOI: $10.1111 /$ jpet.12357.

Martel J. (2018). "Quality, price, and time-on-market”, Economics Letters, Vol. 171, pp. 97-101. DOI: 10.1016/j.econlet.2018.07.025.

Moser H., Fabian M., Jung M., Heutling S., Körber G., Oehme I., Wurbs J., Krause S., Kovacs D., Krüger F., Weiss V. (2016). „Steigerung des Kunststoffrecyclings und des Rezyklateinsatzes" (Increase in plastic recycling and the use of recycled materials). Umweltbundesamt. Position/October 2016. ISSN: 2363-8273.

Plasticker (2019). "bvse Market Report Plastics". New Media Publisher $\mathrm{GmbH}$. Accessed on 17-Sept-2019 at 10:35 a.m.: https://plasticker.de/preise/marktbericht_en.php.

PlasticsEurope (2018). "Plastics - the Facts 2018. An analysis of European plastics production, demand and waste data.". Accessed on 23-Sept-2019 at 12:00 a.m.: https://www.plasticseurope.org/ application/files/6315/4510/9658/Plastics_the_facts_2018_AF_ web.pdf.

Pauwels K., D'Aveni R. (2014). "The formation, evolution and replacement of price-quality relationships". Journal of the Academy of Marketing Science, Vol. 44, Issue 1, pp 46-65. DOI: 10.1007/ s11747-014-0408-3.

Polymer Comply Europe (2017). "Die Verwendung von recycelten Kunststoffen durch Kunststoffverarbeiter in Europa. Eine qualitative europäischeUmfrage in der Industrie. Nationaler Bericht-Deutschland".( The use of recycled plastics by plastic processors in Europe. A qualitative European survey in the industry. National Report - Germany ".) Accessed on 05-May-2019 at 10:30 a.m.: https://www. kunststoffverpackungen.de/ show.php?ID=6240.

Reitz A. (2019): "Herausforderung Kunststoffverpackung. Hemmnisse für Rezyklateinsatz" (Challange plastic packaging. Barriers for the use of recyclates?). Published on 16-May-2019. Accessed on 27Sept-2019 at 00:54 a.m.: https://www.recyclingnews.de/rohstoffe/hemmnisse-fur-rezyklateinsatz/.

Rothgang M., Dehio, J., Janßen-Timmen R. (2017). „Ökonomische Perspektiven des Kunststoffreyclings - die Rolle des dualen Systems" (Economic perspectives of plastic recycling - the role of the Dual System). RWI Materials. Vol. 118. ISBN: 978-3-86788-820-2.

Sarc R., Seidler I.M., Kandlbauer L., Lorber K.E., Pomberger R. (2019): Design, quality and quality assurance of solid recovered fuels for the substitution of fossil feedstock in the cement industry - Update 2019. Waste Management \& Research, Vol. 37, Issue 9, pp. 885-897. DOI: 10.1177/0734242X19862600.

Stoifl B., Bernhardt A., Karigl B., Lampert C., Neubauer M., Thaler P. (2017). „Kunststoffabfälle in Österreich. Aufkommen \& Behandlung. Materialien zum Bundesabfallwirtschaftsplan 2017“ (Plastic waste in Austria. Accumulation and treatment. Materials to the National Waste Economic Plan 2017). Umweltbundesamt. Report REP-0650. Wien. ISBN: 978-3-99004-468-1. Accessed on 27-Sept2019 at 10:35 a.m.: https://www.zeit.de/wirtschaft/2018-01/muellexporte-china-plastikmuell-recycling.

Tecson (2019). „Rohölpreise in jährlicher Entwicklung“ (Yearly crude oil price development). Accessed on 24-Sept-2019 at 10:15 a.m. https://www.tecson.de/oelweltmarkt.html.

Uken M. (2018): "Müllexporte nach China. Die Weltmüllkippe schließt" (Waste exports to China. The worlds waste dump closes). Published on 6-Jan-2018. Accessed on 27-Sept-2019 at 00:54 a.m.: https://www.zeit.de/wirtschaft/2018-01/muellexporte-china-plastikmuell-recycling.

Vilaplana F., Karlsson S. (2008). "Quality concepts for the improved use of recycled polymeric materials: A review". Macromolecular Materials and Engineering. Vol. 273. pp. 274-297. DOI: 10.1002/ mame.200700393.

Voros J. (2019). "An analysis of the dynamic price-quality relationship". European Journal of Operation Research. Vol. 277 Issue 3, pp. 1037-1045. DOI: 10.1016/j.ejor.2019.03.032.

Wallstreet-online (2019). "Euro / US-Dollar (EUR/USD)". Accessed on 24-Sept-2019 at 11:00 a.m.: https://www.wallstreet-online.de/devisen/euro-us-dollar-eur-usd-kurs. 
Wilts H., Gries N. von, Dehne I., Oetjen-Dehne R., Buschow N., Sanden J. (2014): „Entwicklung von Maßnahmen und Instrumenten zur Steigerung des Einsatzes von Sekundärrohstoffen - mit Schwerpunkt Sekundärkunststoffe" (Development of measures and instruments to increase the use of secondary raw materials - with the focus on secondary plastics). UFOPLAN-Vorhaben, FKZ 371233340.

Zhe Jin G., Kato A. (2010): „Price, quality, and reputation: evidence from an online field experiment". RAND Journal of Economics, Vol. 37. No. 4, pp. 983-1005. DOI: 10.1111/j.1756-2171.2006.tb00067.x. 